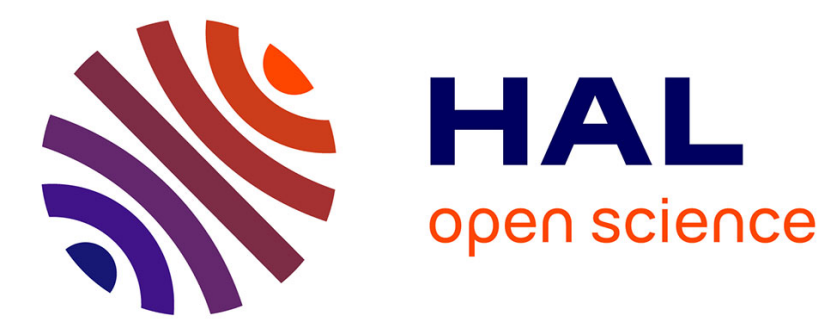

\title{
THE GROWTH OF COLLOIDAL CENTRES IN IRRADIATED ALKALI HALIDES
}

\author{
U. Jain, A. Lidiard
}

\section{To cite this version:}

U. Jain, A. Lidiard. THE GROWTH OF COLLOIDAL CENTRES IN IRRADIATED

ALKALI HALIDES. Journal de Physique Colloques, 1976, 37 (C7), pp.C7-518-C7-519. 10.1051/jphyscol:19767117 . jpa-00216839

\section{HAL Id: jpa-00216839 \\ https://hal.science/jpa-00216839}

Submitted on 1 Jan 1976

HAL is a multi-disciplinary open access archive for the deposit and dissemination of scientific research documents, whether they are published or not. The documents may come from teaching and research institutions in France or abroad, or from public or private research centers.
L'archive ouverte pluridisciplinaire HAL, est destinée au dépôt et à la diffusion de documents scientifiques de niveau recherche, publiés ou non, émanant des établissements d'enseignement et de recherche français ou étrangers, des laboratoires publics ou privés. 


\title{
THE GROWTH OF COLLOIDAL CENTRES IN IRRADIATED ALKALI HALIDES $(*)$
}

\author{
U. JAIN and A. B. LIDIARD \\ Theoretical Physics Division, A. E. R. E., Harwell, Oxon, OX11 ORA, U. K.
}

\begin{abstract}
Résumé. - Cet article est un sommaire des résultats principaux d'une théorie nouvelle de la croissance des colloïdes métalliques dans les halogénures alcalins irradiés. Cette théorie est analogue à celle de la croissance de lacunes dans les métaux irradiés.
\end{abstract}

\begin{abstract}
This article summarises the principal results of a theory of the growth of alkali metal colloids in irradiated alkali halides. The theory draws upon the analogy with void growth in irradiated metals.
\end{abstract}

The alkali halides are very susceptible to radiation damage in the halogen sub-lattice when exposed to ionising radiation - the primary products being F-centres and interstitial halogen atoms (H-centres). Experimental observations have shown that the clustering of the H-centres leads to the formation and growth of perfect interstitial loops [1]. Further recent studies by Hobbs [2] on the growth of colloidal $\mathrm{Na}$ centres by $\mathrm{F}$-centre aggregation in $\mathrm{NaCl}$ irradiated to high doses ( $\sim 25 \mathrm{G}$ Rad which we believe corresponds to $\sim 10$ displacements per anion $(\mathrm{dpa})$ ) in an electron accelerator have shown several features in common with the growth of voids in heavily irradiated metals. In particular, the growth is rapid only over a relatively narrow interval of temperature, say from $\sim 100^{\circ} \mathrm{C}$ to $\sim 200^{\circ} \mathrm{C}$, being most rapid at around $150^{\circ} \mathrm{C}$. At this peak temperature the colloids grow more rapidly than linearly with dose. These observations, taken together with the growth of interstitial loops by $\mathrm{H}$-centre aggregation and the growth of colloids by F-centre aggregation, strongly suggest a close similarity to the formation and growth of voids in heavily irradiated metals, although there are clearly bound to be differences resulting from the compound nature of the solid.

We have therefore constructed a theoretical model suggested by this analogy and by other knowledge of defects and radiation damage in the alkali halides. The theory is very similar to the rate theory of void growth in metals given by Brailsford and Bullough [3] though it differs in detail. Unfortunately, not all the parameters needed for the prediction of colloid growth are known independently with the desired accuracy. However, some can be estimated accurately enough from existing knowledge (e. g. H-centre mobility) or

(*) Summary only: full paper submitted to Philosophical Magazine. can be limited by independent experimental information (e. g. energy of formation of F-centres by thermal dissolution of colloids). Yet others can be taken from the particular irradiation experiments (e. g. colloid density, dislocation loop density). The remainder, namely the F-centre mobility in the radiation field and the rate of production of primary defects by the radiation, unfortunately are not known with sufficient precision, although it is possible to specify the limits to reasonable values. We have therefore adjusted the activation energy for F-centre migration and the rate of production of defects so as to fit the experimental results on colloid growth in $\mathrm{NaCl}$. These and the other parameters are listed in table I. We are then able to

\section{TABLE I}

\section{Assumed Values of Parameters in $\mathrm{NaCl}$}

1. Diffusion coefficient of $H$-centres,

$$
D_{\mathrm{H}}=0.01 \exp (-0.1 \mathrm{eV} / k T) \mathrm{cm}^{2} / \mathrm{s} \text {. }
$$

Corresponding $\mathrm{F}-\mathrm{H}$ recombination rate constant.

2. Diffusion coefficient of F-centres,

$$
\begin{aligned}
K_{2}=10^{14} \exp (-0.1 \mathrm{eV} / k T) \mathrm{s}^{-1} \\
D_{\mathrm{F}}=0.01 \exp (-0.80 \mathrm{eV} / k T) \mathrm{cm}^{2} / \mathrm{s} .
\end{aligned}
$$

3. Mole fraction of F-centres in thermal equilibrium with colloids, $c_{\mathrm{F}}^{(\mathrm{e})}=5.6 \times 10^{-3} \exp (-0.30 \mathrm{eV} / k T)$.

4. Absorbed energy required per primary F-H displacement $=15 \mathrm{eV}$ (giving dose rate $K=10^{-4}$ d. p. a./s. for the experimental conditions of figure 2 , where the rate of energy deposition was $2.5 \times 10^{-4} \mathrm{Grad} / \mathrm{s}$.

5. Density of interstitial dislocation loops,

$$
C_{1}=10^{15} \mathrm{~cm}^{-3} \text {. }
$$

6. Density of colloids, $C_{\mathrm{c}}=10^{15} \mathrm{~cm}^{-3}$.

7. Dislocation bias factors, $z_{\mathrm{F}}=1$ and $z_{\mathrm{H}}=1.1$. 
describe the growth of the colloids in $\mathrm{NaCl}$ as a function of dose and temperature quite accurately (Fig. 1 and 2), though the present experimental data are, in fact, rather few.

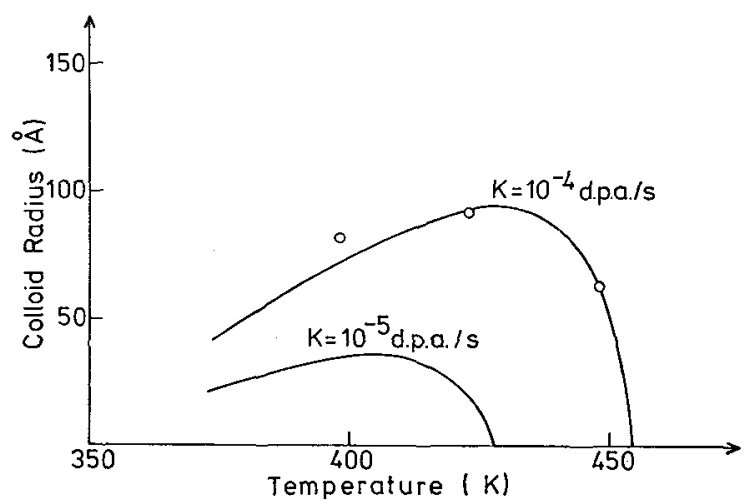

FIG. 1. - The predicted dependence of colloid radius $(\AA)$ in $\mathrm{NaCl}$ after a total dose of $6 \mathrm{~d}$. p. a. upon the temperature of irradiation for two different dose rates as indicated (other parameters as in table I). The circles are experimental points (Hobbs, private communication) corresponding to a total measured dose of $15 \mathrm{Grad}$.

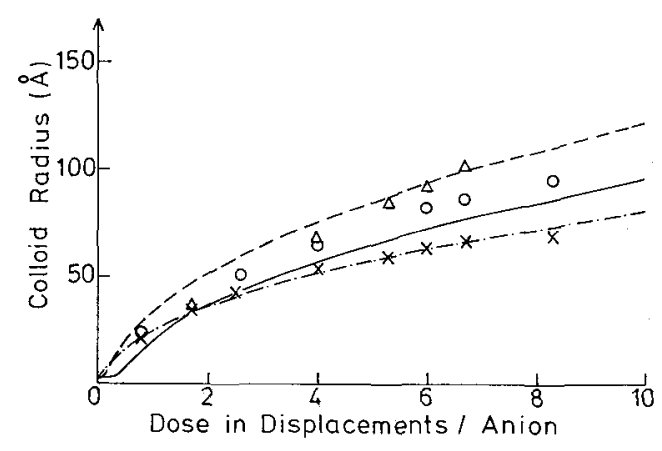

FIG. 2. - The predicted dose dependence of colloid radius in $\mathrm{NaCl}$ at temperatures of $398 \mathrm{~K}(-), 423 \mathrm{~K} \mathrm{(-} \mathrm{-} \mathrm{-)} \mathrm{and} 448 \mathrm{~K}$ $(-:-$.$) ; parameters as in table I. Corresponding experimental$ points are also shown for irradiation at a dose rate of $2.5 \times 10^{-4} \mathrm{Grad} / \mathrm{s} ; 0398 \mathrm{~K}, \triangle 423 \mathrm{~K}$ and $\times 448 \mathrm{~K}$ (Hobbs, private communication).

The rise of the accompanying F-centre concentration in the early stages of irradiation before significant

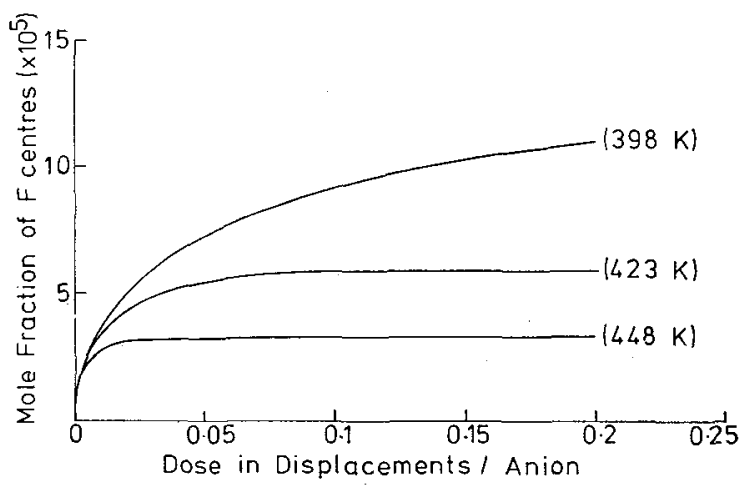

Fig. 3. - The predicted dose dependence of F-centre concentration in $\mathrm{NaCl}$ at temperatures $398 \mathrm{~K}, 423 \mathrm{~K}$ and $448 \mathrm{~K}$.

colloid growth has occurred is shown in figure 3. Except at the very earliest times this growth follows closely the law

$$
c_{\mathrm{F}}=c_{\mathrm{F}}^{\text {sat }}\left(1-\mathrm{e}^{-2 K_{1} t}\right)^{1 / 2}
$$

in which $c_{\mathrm{F}}$ is the mole fraction of F-centres, $t$ is the time of irradiation and $K_{1}$ is the rate constant determining the loss of F-centres to colloids and dislocations. The steady state value of $\mathcal{c}_{\mathrm{F}}$ is given approximately by

$$
c_{\mathrm{F}}^{\mathrm{sat}}=\left(\frac{K D_{\mathrm{H}}}{K_{2} D_{\mathrm{F}}}\right)^{1 / 2}
$$

in which $K$ is the rate of production of defects, $D_{\mathrm{H}}$ and $D_{\mathrm{F}}$ are respectively the $\mathrm{H}$-centre and F-centre mobilities, while $K_{2}$ is the rate constant for the loss of Hcentres to colloids and dislocations. Since $K_{2}$ is proportional to $D_{\mathrm{H}}$ the temperature dependence of $c_{\mathrm{F}}^{\text {sat }}$ should thus be closely equal to that of $D_{\mathrm{F}}^{-1 / 2}$. It appears that these results can explain some of the hitherto puzzling features of previous observations by Sonder and Templeton [4] of F-centre production in $\mathrm{KCl}$ at temperatures where $\mathrm{F}$-centres are mobile. More stringent tests of the theory would nevertheless be provided by more extensive measurements of the growth of colloids and of the accompanying F-centre concentrations.

\section{References}

[1] Hobis, L. W., Hughes, A. E. and Pooley, D., Proc. $R$. Soc. London A 332 (1973) 167.

[2] Hoвbs, L. W., in Surface and Defect Properties of Solids, (Chemical Society Specialist Periodical Reports) Vol. 4 (1975) 152. Also J. Physique Colloq. 37 (1976) C7, this issue.
[3] Brailsford, A. D. and Bullough, R. Proceedings of the British Nuclear Energy Society Conference on Irradiation Embrittlement and Creep in Fuel Cladding and Core Components held in London 9-10 November (1972) p. 267.

[4] Sonder, E. and Templeton, L. C., Phys. Rev. 164 (1967) 1106. 